DOI: https://doi.org/10.24127/ajpm.v10i2.3462

\title{
ANALISIS KESALAHAN SISWA DALAM TES KEMAMPUAN BERPIKIR KREATIF MATERI PECAHAN BERDASARKAN ANALISIS NEWMAN
}

\author{
Asri Dwita $^{1 *}$, Sugiman ${ }^{2}$ \\ 1* Program Magister Pendidikan Matematika FMIPA UNY, Yogyakarta, Indonesia \\ ${ }^{2}$ Jurusan Pendidikan Matematika UNY, Yogyakarta, Indonesia \\ * Pagaralam, 31511, Pagaralam, Indonesia. \\ E-mail: $\quad$ asridwita.2019@student.uny.ac.id $^{\left.{ }^{*}\right)}$
}

Received 06 January 2021; Received in revised form 18 June 2021; Accepted 28 June 2021

\begin{abstract}
Abstrak
Pada abad 21, Kemampuan berpikir kreatif sangat diperlukan sehingga kemampuan tersebut perlu diperhatikan. Penelitian ini membahas tentang kesalahan siswa dalam menjawab soal tes kemampuan berpikir kreatif matematis pada materi pecahan berdasarkan prosedur Newman. Penelitian ini bertujuan untuk memberi informasi mengenai kesalahan yang mungkin dilakukan siswa terkait soal-soal tes kemampuan berpikir kreatif materi pecahan. 13 siswa SMP di Pagaralam yang berada di kelas VII merupakan subjek penelitian. Penelitian ini menggunakan metode descriptive-qualitative. Instrumen yang digunakan adalah soal-soal esai tes kemampuan berpikir kreatif dengan indikator-indikator yaitu kelancaran, fleksibilitas dan kebaruan. Hasil penelitian menunjukkan bahwa siswa melakukan kesalahan dalam Reading, Comprehension, Transformation, Process Skill, dan Encoding berdasarkan prosedur Newman. Penelitian ini menyatakan bahwa kesalahan dalam reading menyebabkan siswa tidak mencapai indikator kelancaran dengan maksimal. Kesalahan pada comprehension menyebabkan siswa tidak dapat mencapai indikator fleksibelitas dengan maksimal. Selain itu, pencapaian pada indikator kebaruan perlu didukung oleh kemampuan siswa untuk menjawab soal tanpa melakukan.kesalahan.
\end{abstract}

Kata kunci: Analisis Newman; kemampuan berpikir kreatif; kesalahan siswa.

\begin{abstract}
In $21^{\text {st }}$ century, creative thinking ability is required, so this ability needs to be considered. This study will discuss students' mistakes in answering the mathematical creative thinking ability test questions on fraction material regarding to Newman procedure. The goal of this is to give information about students' mistakes regarding fraction material of creative thinking ability test. 13 junior high school students in Pagaralam in class VII are the subjects in this research. This research used descriptive-qualitative method. In this case, the instruments used are essay questions of creative thinking skills under indicators namely fluency, flexibility and novelty. The results showed that students made mistakes in Reading, Comprehension, Transformation, Process Skills, and Encoding based on Newman's procedures. This study found that reading error causes students can not reach the maximum score of fluency indicator. Errors in comprehension causes students are unable to achieve maximum score of flexibility indicator. In addition, achievement of novelty indicator needs to be supported by students' ability to answer questions without making mistakes.
\end{abstract}

Keywords: Creative thinking skills; Newman analysis; students error.

This is an open access article under the Creative Commons Attribution 4.0 International License

\section{PENDAHULUAN}

Kemampuan berpikir kreatif merupakan kemampuan yang berhubungan dengan pemikiran divergen yang berkaian dengan sintesis, investigasi, dan penerapan ide-ide baru beserta jawaban permasalahan (Sanders, 2016). 
Jadi, kemampuan yang menuntut siswa untuk dapat mengeneralisasi bermacammacam jawaban lebih dari satu adalah kemampuan berpikir kreatif

Kemampuan berpikir kreatif tidak terlepas dari adanya kreativitas. Kreativitas merupakan hal yang diperlukan di dunia kerja pada abad 21 (Syaibani, Dafik, \& Hobri, 2017). Artinya, keberhasilan dalam berpikir kreatif atau kreativitas adalah hal yang diperlukan. Lebih lanjutnya, terdapat beberapa indikator yang menentukan keberhasilan dalam berpikir kreatif. Siswono (2011) menyatakan bahwa kemampuan berpikir kreatif memiliki indikator yaitu Fluency (Kelancaran), flexibility (fleksibelitas) dan Novelty (Kebaruan). Kelancaran adalah kemampuan untuk mengeluarkan ideide yang benar. Fleksibelitas merujuk pada kemampuan untuk menjawab soal dengan cara-cara yang bervariasi. Kebaruan berupa kemampuan untuk mengeluarkan jawaban yang unik. Dalam hal ini, baik atau tidaknya kemampuan berpikir kreatif terlihat dari pencapaian indikator-indikatornya.

Kemampuan berpikir kreatif matematis perlu dikuasai oleh siswa. Namun, penelitian Fardah (2012) menyatakan bahwa ada $20 \%$ yang memiliki kemampuan berpikir kreatif pada kategori tinggi, 33,33\% siswa memiliki kemampuan berpikir kreatif kategori sedang, 46,67\% siswa dengan kategori rendah. Artinya, siswa yang berkemampuan berpikir kreatif rendah mendominasi pada sampel tersebut. Di sini terlihat bahwa kemampuan berpikir kreatif siswa masih belum baik.

Rendahnya kemampuan siswa bisa disebabkan oleh siswa mengalami kesulitan dalam pembelajaran. Dalam hal ini, kesulitan dalam belajar memiliki dampak pada prestasi yang dicapai siswa (Jamal, 2014). Untuk mata pelajaran matematika, siswa bisa saja menemukan kesulitan saat mengerjakan soal cerita pada materi pecahan (Aminah \& Kurniawati, 2018). Kesulitan-kesulitan siswa dalam materi tersebut adalah hal yang perlu atasi karena dapat menyebabkan siswa melakukan kesalahan dalam menyelesaikan permasalahan.

Berdasarkan alasan-alasan di atas, kesalahan-kesalahan pada tes kemampuan berpikir kreatif pada materi pecahan adalah hal yang perlu dideteksi. Penelitian-penelitian terdahulu seperti (Fatahillah, Wati, \& Susanto, 2017) telah meneliti tentang analisis kesalahan siswa dalam materi pecahan menurut prosedur Newman namun soal-soal yang diberikan terbatas hanya pada soal cerita biasa. Penelitian ini bermaksud untuk mengkaji lebih dalam kesalahankesalahan siswa dalam mengerjakan tes kemampuan berpikir kreatif materi pecahan. Untuk memperoleh hasil analisis yang dalam, prosedur analisis kesalahan siswa menggunakan prosedur newman Reading, Comprehension, Transformation, Process Skill, dan Encoding (White, 2010). Soal-soal tes materi pecahan yang dianalisis merupakan soal-soal tes kemampuan berpikir kreatif materi pecahan. Penelitian ini bertujuan untuk menganalisis kesalahan siswa dalam menjawab soal tes kemampuan berpikir kreatif ditinjau dari prosedur Newman.

\section{METODE PENELITIAN}

Penelitian ini memiliki tujuan untuk menganalisis kesalahan siswa pada tes kemampuan berpikir kreatif matematis berdasarkan analisis Newman. Descriptive-qualitative merupakan metode dalam penelitian ini. Kemampuan berpikir kreatif materi pecahan dianalisis berdasarkan kategori Newman. 
DOI: https://doi.org/10.24127/ajpm.v10i2.3462

Siswa-siswa SMP secara acak di Pagaralam yang berada di kelas VII merupakan subjek penelitian. Siswasiswa tersebut berjumlah 13 orang dan beberapa diantaranya akan dianalisis kesalahan-kesalahan dalam menjawab tes kemampuan berpikir kreatif. Sampel merupakan siswa-siswa yang telah mempelajari materi pecahan.

Dalam penelitian ini, data dikumpulkan dari soal tes kemampuan berpikir kreatif matematis. Indikatorindikator yang digunakan adalah kelancaran, fleksibilitas dan kebaruan. Soal yang digunakan dalam penelitian ini berupa soal kemampuan berpikir kreatif. Soal-soal yang diberikan tersebut berupa tes berbentuk esai yang berjumlah tiga soal. Validitas dan reliabelitas butir-butir soal berada dalam kategori tinggi sehingga dianggap layak untuk digunakan. Kemudian data yang diperoleh dianalisis.

Pada penelitian ini, data dianalisis menggunkan prosedur Newman. Model yang digunakan adalah Newman Error Analysis (NEA) (Alhassora, Abu, \& Abdullah, 2017). Tahapan dalam prosedur tersebut adalah reading dan decoding, Comprehension, Transformation, Process Skills dan Encoding. Langkah-langkah yang dilakukan adalah mengklasifikasi kesalahan siswa berdasarkan NEA dan menganalisisnya secara kualitatif.

\section{HASIL DAN PEMBAHASAN}

Pada penelitian ini, instrumen penilaian kemampuan berpikir kreatif terdiri atas tiga soal. Soal-soal tersebut dikembangkan berdasarkan indikator kelancaran, keluwesan dan kebaruan. Setelah siswa melaksanakan tes tertulis, jawaban-jawaban siswa dikoreksi. Ratarata skor tes kemampuan berpikir kreatif matematis dapat dilihat pada Tabel 1.
Tabel 1. Deskripsi skor indikatorindikator kemampuan berpikir kreatif

\begin{tabular}{lccc}
\hline Indikator & $\begin{array}{c}\text { Skor } \\
\text { Maksimal }\end{array}$ & $\begin{array}{c}\text { Rata- } \\
\text { rata }\end{array}$ & $\begin{array}{c}\text { Persen- } \\
\text { tase }\end{array}$ \\
\hline kelancaran & 12 & 5 & $42 \%$ \\
\hline keluwesan & 12 & 5.8 & $48 \%$ \\
\hline kebaruan & 12 & 1.8 & $15 \%$ \\
\hline
\end{tabular}

Berdasarkan data pada Tabel 1, terlihat bahwa persentase semua indikator belum mencapai $50 \%$. Hal tersebut senada dengan penelitian (Rasnawati, Rahmawati, Akbar, \& Putra, 2019). Hal yang paling menonjol adalah skor yang didapatkan siswa pada indikator kebaruan hanya mencapai 15\%. Artinya, kebanyakan siswa tidak menjawab permasalahan dengan cara yang berbeda dengan siswa lainnya. Hal ini sejalan dengan penelitian (Siregar, 2017). Selain itu, rendahnya pencapaian siswa pada indikator kelancaran dengan presentase $42 \%$ dan keluwesan dengan presentasi $48 \%$ menunjukkan bawa siswa tidak dapat mencetuskan ide-ide dengan baik dan siswa tidak menyelesaikan permasalahan dengan cara yang beragam.

Jawaban-jawaban yang diberikan siswa berdasarkan soal yang telah diberikan memiliki kesalahan. Dalam hal ini, kesalahan-kesalahan siswa lebih rinci dijelaskan berdasarkan prosedur Newman yaitu reading and decoding, Comprehension, Transformation, Process Skills, dan Encoding. Terdapat berbagai kesalahan siswa dalam mengerjakan seperti yang terliaht pada Gambar 1 dimana Gambar 1 merupakan jawaban siswa 01 yang melakukan kesalahan Reading and Decoding, Comprehension, Transformation, dan Encoding. Lebih jelasnya dapat dengan seksama pada Gambar 1. 
DOI: https://doi.org/10.24127/ajpm.v10i2.3462

a. Berapa takar gula yang diperlukan untuk membuat kue tersebut?

$$
\begin{aligned}
\text { Jelaskan! }=\frac{1}{2} \times 10 & =5 \mathrm{~kg} \\
\frac{3}{2} \times 10 & =15 \mathrm{~kg} \\
\frac{5}{2} \times 10 & =25 \mathrm{~kg} \\
\frac{7}{2} \times 10 & =35 \mathrm{~kg} \rightarrow \frac{80}{10}=8
\end{aligned}
$$

Gambar 1. Contoh jawaban kesalahan siswa 01 pada soal nomor 1

Berdasarkan Gambar 1, siswa melakukan berbagai kesalahan. Dalam hal ini, siswa melakukan kesalahan pada reading and decoding dimana siswa tidak memahami permasalahan sehingga jawaban yang didapatkan melenceng jauh dari yang diharapkan. Hal tersebut juga menyebabkan siswa tidak dapat mengeluarkan ide yang benar untuk menjawab permasalahan sehingga tidak mencapai indikator kelancaran pada kemampuan berpikir kreatif. Kesalahan dalam aspek ini dapat disebabkan karena siswa hanya menjawab dengan spekulasinya dan tidak memiliki keyakinan dalam menyelesaian soal dengan (Junaedi, 2012). Berdasarkan jawaban yang dibuat siswa, siswa salah dalam memaknai pertanyaan. Dalam hal tersebut, siswa menjawab berapa gula yang dapat dimuat takaran dan bukan takaran-takaran mana saja untuk menghasilkan $10 \mathrm{~kg}$ gula. Hal ini berhubungan juga dengan kesalahan siswa dalam comprehension. Siswa tidak memahami permasalahan yang diberikan sehingga melakukan kesalahan dalam membuat ekspresi matematis guna menyelesaikan masalah. Selain itu, meskipun siswa menjawab soal-soal dengan berbagai cara, namun cara-cara yang dilakukan siswa tersebut tidak benar karena kesalahan pemahaman. Siswa juga mengalami kesalahan dalam transformation dimana siswa tidak menggunakan strategi yang relevan untuk menyelesaikan permasalahan. Selain itu, terdapat juga kesalahan pada encoding, dimana siswa tidak mampu untuk memberikan alasan dari jawaban yang ia peroleh.

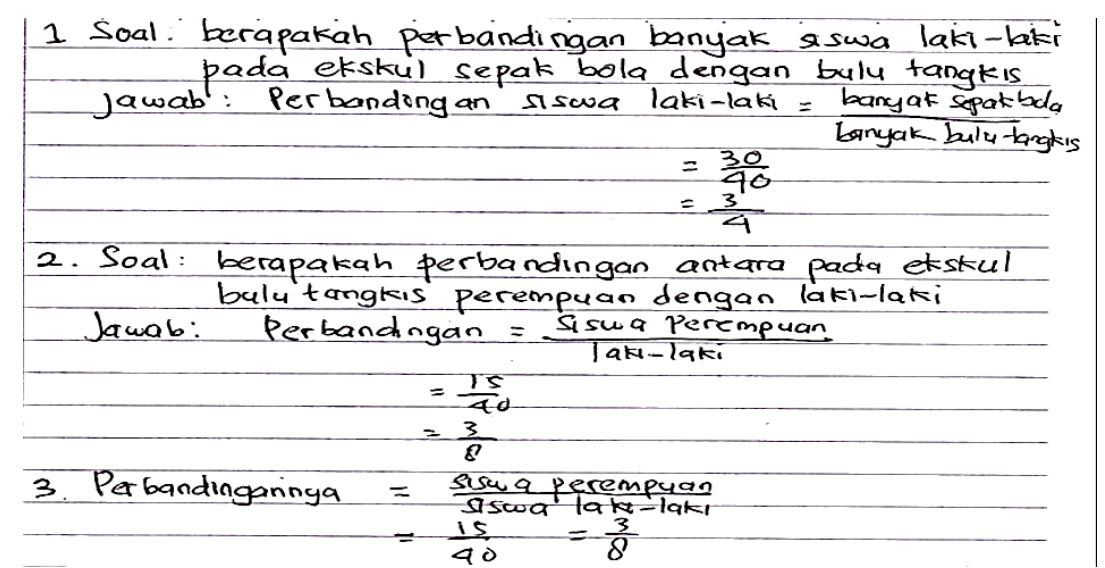

Gambar 2. Contoh jawaban siswa 02 yang salah pada soal nomor 2 
DOI: https://doi.org/10.24127/ajpm.v10i2.3462

Gambar 2 merupakan jawaban siswa 02 yang melakukan kesalahan Reading and Decoding, Comprehension, Transformation, Process Skills dan Encoding dalam menjawab soal nomor 2. Pertanyaan nomor dua merupakan pertanyaan yang ingin melihat kemampuan berpikir kreatif siswa dalam membuat soal dari permasalahan yang diberikan. Dalam hal ini, siswa salah dalam mengartikan pecahan dan perbandingan. Pertanyaan yang diminta adalah membuat soal tentang pecahan. Artinya, siswa melakukan kesalahan Reading and
Decoding. Dalam hal ini, siswa belum memahami dengan jelas masalah yang diberikan. Akibatnya, siswa tidak dapat mengeluarkan ide-ide yang benar dalam menyelesaikan permasalahan sehingga tidak dapat mencapai hasil yang maksimal pada indikator kelancaran kemampuan berpikir kreatif. Kesalahan Reading and Decoding dalam hal ini menyebabkan terjadinya kesalahan juga pada Comprehension, Transformation, Process Skills, dan Encoding serta setiap cara yang dilakukan siswa dalam menyelesaikan permasalahan salah.

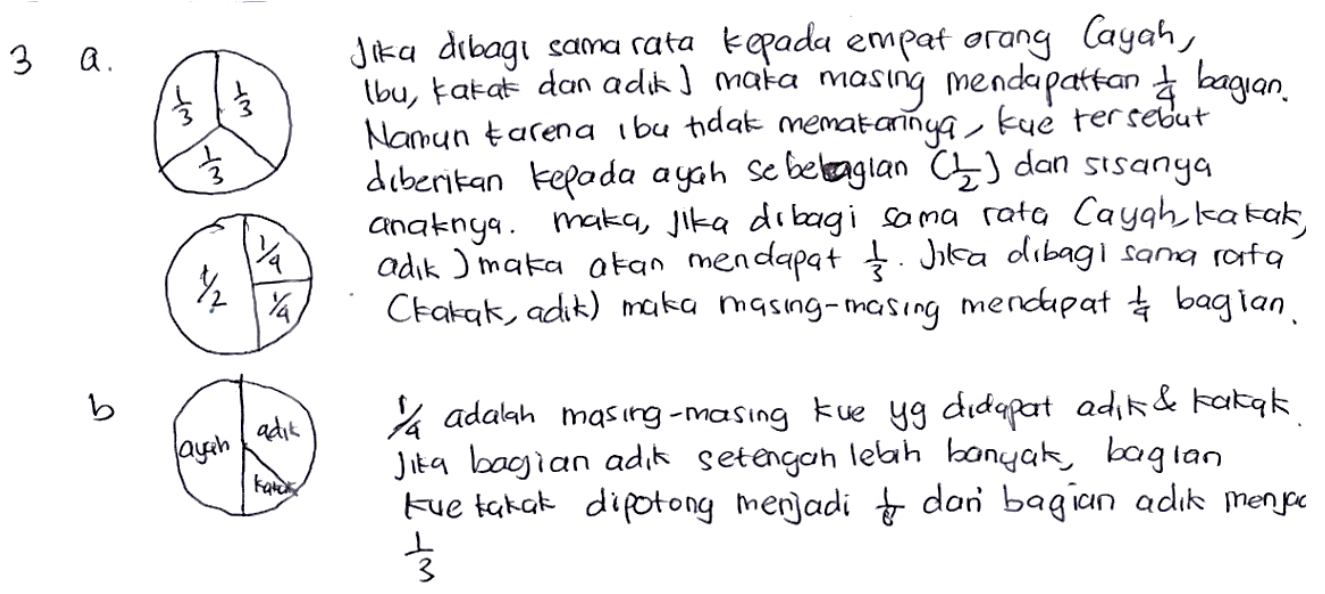

Gambar 3. Contoh jawaban kesalahan siswa 03 pada soal nomor 3

Gambar 3 merupakan jawaban siswa 03 yang melakukan kesalahan dalam menjawab soal nomor 3. Dalam hal tersebut, siswa sudah benar dalam menjawab soal nomor 3a. Namun, siswa salah dalam reading and decoding pada 3b. Kesalahan tersebut tampak dari siswa salah dalam menulis yang dikatahui dari soal. Siswa salah dalam memahami soal yang menyebabkannya menjawab per-masalahan dengan ideide yang salah. Hal tersebut menyebabkan siswa tidak bisa mencapai nilai maksimal pada indikator kelancaran kemampuan berpikir kreatif. Siswa menulis yang diketahui adalah bagian adik setengah lebih banyak sedangkan yang diketahui di soal adalah bagian adik memiliki kue paling banyak setengah dari bagian kakak. Selanjutnya, terdapat kesalahan siswa dalam Comprehension. Siswa menjawab dengan konsep yang salah dimana siswa tersebut secara tidak langsung menyatakan bahwa $\frac{1}{8}$ lebih dari $\frac{1}{3}$. Dalam hal ini, pemahaman konsep dasar siswa masih belum benar. Hal ini sejalan dengan penelitian Permadi \& Irawan (Permadi \& Irawan, 2016) yang menemukan kesalahan konsep pada materi pecahan. Siswa juga tidak menuliskan strategi dan langsung menjawab permasalahan tanpa proses. 
DOI: https://doi.org/10.24127/ajpm.v10i2.3462

Hal tersebut menunjukkan indikasi kesalahan siswa dalam Transformation dan Process Skills. Meskipun demikian, siswa tersebut dapat menuliskan alasan dari jawaban walau jawabannya salah. Artinya, siswa berusaha untuk menemukan jawaban namun kesalahan siswa dalam Encoding terjadi dalam menjawab soal tersebut.

Kesalahan-kesalahan siswa yang diidentifikasi berdasarkan prosedur Newman berimpikasi pada pencapaian indikator kelancaran dan fleksibilitas. Pada indikator kebaruan, indikator kebaruan merupakan indikator yang berada di posisi tertinggi karena indikator tersebut merupakan karakteristik utama untuk menilai kemampuan berpikir kreatif (Siswono, 2011). Dalam hal ini, kebaruan berhubungan dengan menghasilkan solusi baru yang tidak diduga-duga (Nadjafikhah \& Yaftian, 2013). Solusi baru tersebut bernilai benar ketika jawaban tersebut benar. Selain itu, dasar dari kebaruan berhubungan dengan mengaktifkan contoh dari suatu kategori, mendukung pemikiran yang berbeda dan memperluas kategorikategori yang dapat dibuat untuk menyelesaikan permasalahan (Gillebaart, Förster, Rotteveel, \& Jehle, 2013). Artinya, pencapaian pada indikator kebaruan tidak hanya didukung oleh kemampuan siswa untuk tidak melakukan kesalahan menjawab soal namun juga memerlukan pemikiran mendalam dari siswa untuk mendapatkan solusi yang baru. Sejalan dengan hasil penelitian ini, siswa melakukan kesalahan dalam penelitian Aminah \& Kurniawati (2018), siswa dapat melakukan kesalahan dalam Reading, Comprehension, Transformation, Process Skill, dan Encoding pada soal-soal materi pecahan. Dengan demikian, kesalahan-kesalahan dalam penyelesaian tes kemampuan berpikir kreatif pada materi pecahan merupakan hal yang mungkin terjadi sehingga guru perlu menanggulangi dan mencegah terjadinya kesalahan-kesalahan tersebut.

Dari hasil dan pembahasan di atas, siswa salah memahami maksud dari soal sehingga melakukan kesalahan dalam reading, salah dalam memahami konsep yang ada dalam soal sehingga melakukan kesalahan dalam Comprehension, tidak menggunakan strategi untuk menyelesaikan permasalahan dan langsung menjawab tanpa proses sehingga melakukan kesalahan Transformation dan Process Skill. Siswa juga tidak memberikan alasan dari jawaban yang telah diperoleh sehingga melakukan kesalahan pada Encoding. Selain itu, kesalahan dalam reading dimana siswa tidak memahami pertanyaan menyebabkan siswa kesulitan mengeluarkan ide-ide guna menyelesaikan permasalahan sehingga tidak mencapai indikator kelancaran dengan maksimal. Kesalahan pada comprehension dimana siswa tidak memahami konsep menyebabkan kesalahan pada setiap jawaban-jawaban siswa sehingga siswa tidak dapat mencapai indikator fleksibelitas kemampuan berpikir kreatif dengan maksimal. Selain itu, pencapaian pada indikator kebaruan perlu didukung oleh kemampuan siswa untuk menjawab soal tanpa melakukan.kesalahan. Dengan demikian, ditemukan bahwa tidak tercapainya indikator kemampuan berpikir kreatif selaras dengan terdapatnya kesalahankesalahan jawaban siswa berdasarkan prosedur Newman.

Dampak dari hasil penelitian ini yaitu memberikan gambaran kepada guru mengenai kesalahan-kesalahan berdasarkan prosedur Newman yang mungkin dilakukan siswa dalam 
mengerjakan tes kemampuan berpikir kreatif materi pecahan. Dalam hal ini, guru hendaknya dapat menganalisis pembelajaran dengan kegiatan-kegiatan seperti apa yang meminimalisir kesalahan-kesalahan siswa dalam menjawab soal-soal kemampuan berpikir kreatif yang berkaitan dengan materi pecahan.

\section{KESIMPULAN DAN SARAN}

Penelitian ini disimpulkan bahwa siswa melakukan kesalahan reading, comprehension, transformation, process skill, dan encoding dalam mengerjakan soal-soal kemampuan kemampuan berpikir kreatif matematis materi pecahan. Dalam hal ini, tidak tercapainya indikator kemampuan berpikir kreatif selaras dengan terdapatnya kesalahan-kesalahan jawaban siswa berdasarkan prosedur Newman.

Penelitian ini hanya terbatas pada materi pecahan kelas VII SMP sehingga disarankan untuk penelitian lanjut pada tingkat lain yang juga mempelajari materi pecahan, seperti pada tingkat sekolah dasar. Penelitian ini diharapkan menjadi data pendukung bagi guru-guru dalam mendiagnosa kesalahankesalahan yang mungkin siswa lakukan saat mengerjakan soal pecahan sehingga menjadi landasan bagi mereka dalam mempertimbangkan hal-hal perlu ditekankan dalam pembelajaran materi pecahan.

\section{DAFTAR PUSTAKA}

Alhassora, N. S. A., Abu, M. S., \& Abdullah, A. H. (2017). Newman Error Analysis on Evaluating and Creating Thinking Newman Error Analysis on Evaluating and. Man In India, 97(19), 413-427. Retrieved from http://home.hiroshimau.ac.jp/cice/wp-
content/uploads/publications/Jour nal9-1/9-1-9.pdf.

Aminah, A., \& Kurniawati, K. R. A. (2018). Analisis Kesulitan Siswa Dalam Menyelesaikan Soal Cerita Matematika Topik Pecahan Ditinjau Dari Gender. JTAM | Jurnal Teori Dan Aplikasi Matematika, 2(2), 118. https://doi.org/10.31764/jtam.v2i2 .713.

Fardah, D. K. (2012). Analisis Proses dan Kemampuan Berpikir Kreatif Siswa dalam Matematika Melalui Tugas Open-Ended. Kreano: Jurnal Matematika KreatifInovatif, 3(2), 91-99. https://doi.org/10.15294/kreano.v $3 \mathrm{i} 2.2616$.

Fatahillah, A., Wati, Y. F., \& Susanto. (2017). Analisis Kesalahan Siswa dalam Menyelesaikan Soal Cerita Matematika berdasarkan Tahapan Newman beserta Bentuk Scaffolding yang diberikan. Kadikma, 8(1), 40-51.

Gillebaart, M., Förster, J., Rotteveel, M., \& Jehle, A. C. M. (2013). Unraveling Effects of Novelty on Creativity. Creativity Research Journal, 25(3), 280-285. https://doi.org/10.1080/10400419. 2013.813781 .

Jamal, F. (2014). Analisis Kesulitan Belajar Siswa Pada Materi Peluang | 18. Jurnal MAJU (Jurnal Pendidikan Matematika), 1(1), 18-36.

Junaedi, I. (2012). Tipe Kesalahan Mahasiswa dalam Menyelesaikan Soal-Soal Geometri Analitik Berdasar Newman's Error Analysis (NEA). Kreano, Jurnal Matematika Kreatif-Inovatif, 3(2), 125-133. https://doi.org/10.15294/kreano.v $3 \mathrm{i} 2.2872$. 
DOI: https://doi.org/10.24127/ajpm.v10i2.3462

Nadjafikhah, M., \& Yaftian, N. (2013). The Frontage of Creativity and Mathematical Creativity. Procedia - Social and Behavioral Sciences, 90(InCULT 2012), 344350.

https://doi.org/10.1016/j.sbspro.20 13.07.101.

Permadi, W. E., \& Irawan, E. B. (2016). Memahamkan Konsep Pecahan Pada Siswa Kelas Iv Sdn Sumberejo 03 Kabupaten Malang. Jurnal Pendidikan, Teori,Penelitian Dan

Pengembangan, 1(9), 1735-1738.

Rasnawati, A., Rahmawati, W., Akbar, P., \& Putra, H. D. (2019). Analisis Kemampuan Berfikir Kreatif Matematis Siswa SMK Pada Materi Sistem Persamaan Linier Dua Variabel (SPLDV) Di Kota Cimahi. Jurnal Cendekia: Jurnal Pendidikan Matematika, 3(1), 164-177.

https://doi.org/10.31004/cendekia. v3i1.87.

Sanders, S. (2016). Critical and creative thinkers in mathematics classrooms. Journal of Student Engagement: Education Matters, 6(1), 19-27.

Siregar, H. M. (2017). Analisis Kesalahan Siswa dalam Menyelesaikan Soal Tes Kemampuan Berpikir Kreatif Matematis Materi Lingkatan. Jurnal Program Studi Pendidikan Matematika, 8(3), 497-507. https://doi.org/10.1017/CBO9781 107415324.004.

Siswono, T. Y. E. (2011). Level of student's creative thinking in classroom mathematics. Educational Research and Reviews, 6(7), 548-553.

Syaibani, H. A., Dafik, \& Hobri. (2017). The Analysis of Student's
Creative Thinking Skills in Solving "Rainbow Connection" Problem through Research Based Learning. The International Journal of Social Sciences and Humanities Invention, 4(7), 37833788 . https://doi.org/10.18535/ijsshi/v4i 8.14 .

White, A. L. (2010). Numeracy, Literacy and Newman's Error Analysis. Journal of Science and Mathematics Education in Southeast Asia, 33(2), 129-148. 